\title{
Suppression by the ColV,I-K94 Plasmid of a Growth Lesion in ompA Mutants of Escherichia coli
}

\author{
By CAROLINE M. M. DEENEY, MARGARET GOODSON, \\ FREDA T. ROSSOUW AND ROBIN J. ROWBURY* \\ Department of Botany and Microbiology, University College London, Gower Street, \\ London WC1E 6BT, UK
}

(Received 14 November 1985 ; revised 10 March 1986)

\begin{abstract}
Organisms of three independently isolated $\operatorname{omp} A$ mutants of Escherichia coli failed to form colonies on glucose minimal agar (glucose MA) at $44{ }^{\circ} \mathrm{C}$ after growth in glucose minimal salts medium at $37{ }^{\circ} \mathrm{C}$, although all three strains formed colonies on nutrient agar at $44^{\circ} \mathrm{C}$. Supplementation of the glucose MA with individual amino acids including L-methionine and/or L-cysteine did not allow colony formation at $44^{\circ} \mathrm{C}$, although addition of $0.1 \%$ Casamino acids was effective; replacement of glucose with other energy sources or ammonium ions with glutamate also did not allow growth at $44{ }^{\circ} \mathrm{C}$. The failure to form colonies at $44{ }^{\circ} \mathrm{C}$ was not due to killing of the organisms, because colonies were formed if plates of the $\mathrm{omp} A$ mutant initially incubated at $44{ }^{\circ} \mathrm{C}$ were shifted to $30^{\circ} \mathrm{C}$ after $16 \mathrm{~h}$. Introduction of the ColV, I-K94 plasmid into P678-54 ompA, 1131 ompA or an ompC ompA mutant suppressed the $44^{\circ} \mathrm{C}$ growth lesion, but other plasmids (F lac, R483ColIa, RI, ColB-K98, R124) tested in P678-54 ompA did not. Growth of the ColV, I-K94+ derivative at $44{ }^{\circ} \mathrm{C}$ was due to a suppressing effect of the plasmid rather than to introduction of the plasmid into a variant with normal or altered OmpA protein. An attempt was made to ascertain which component(s) encoded by ColV, I-K94 was (were) responsible for allowing growth at $44^{\circ} \mathrm{C}$. Transfer components appeared unlikely to be involved and plasmids which conferred individual colicins (plus the corresponding immunity component) did not suppress. The findings that the ColV, I-K94-encoded VmpA protein resembles the OmpA protein $(a)$ immunologically and $(b)$ in being a transmembrane component of the outer membrane suggested that it might be the presence of the $\mathrm{VmpA}$ protein which allowed growth at $44{ }^{\circ} \mathrm{C}$. Several experiments were in accord with this possibility.
\end{abstract}

\section{INTRODUCTION}

The outer membrane of strains of Escherichia coli contains a few so-called major proteins in very large amounts. In $E$. coli $\mathrm{K} 12$ derivatives there are four such proteins under most cultural conditions, the lipoprotein and the OmpA, OmpC and OmpF proteins (Lugtenberg et al., 1975). Aside from their functioning as phage receptors and in colicin attachment or conduction, important functions have been established for the $\mathrm{OmpC}$ and $\mathrm{OmpF}$ proteins as porins for small hydrophilic molecules (Luktenhaus, 1977), whilst the lipoprotein has been implicated in attachment of the outer membrane to the murein layer (Braun, 1978). In contrast, although the OmpA protein acts as a receptor (e.g. for phages $\mathrm{K} 3$ and TuII*), as a component in colicin $\mathrm{L}$ conduction and in stabilization of conjugal aggregates (Skurray et al., 1974; Manning et al., 1977), its specific role in normal growth has not been precisely defined. On the basis that glutamine and proline are taken up less well by $o m p A$ strains than by $o m p A^{+}$ones, there is the possibility of a porin function for the protein (Manning et al., 1977), although the properties of the OmpA protein differ markedly from those of the other porins (Nikaido, 1979). The finding that ompA mutants lose viability in stationary phase might, however, indicate a more general role for OmpA protein in morphogenesis or in membrane or envelope stability or integrity 
(Manning et al., 1977), a role also suggested by studies of morphological mutants (Sonntag et al., 1978).

The OmpA protein is a transmembrane protein of 325 amino acids (Chen et al., 1980). Of these, about 148, at the $C$ terminal region, protrude inwards into the periplasmic space (Chen $e t$ $a l ., 1980$ ). A loop (at residues about 60-70) appears to protrude to the outside (Cole et al., 1983); it is possible that about $70 \mathrm{~N}$ terminal residues protrude, since this segment becomes sensitive to proteolytic enzymes in one ompA mutant (Cole et al., 1983). Other loops of the OmpA protein chain may protrude to the outside (e.g. at residues about 110 and 154; Morona et al., 1984), but substantial numbers of amino acids appear to be buried in the membrane. It is this part of the protein which might play a role in permeation or in membrane integrity under certain conditions.

The plasmid ColV, I-K94 is a colicinogenic plasmid which resembles $\mathrm{F}$ in transfer properties and incompatibility (Hardy, 1975). Like F, ColV, I-K94 confers derepressed transfer properties on strains which carry it. Additionally, it encodes the production of the major VmpA protein (Rowbury et al., 1985) and the secretion of colicin V and colicin Ia as well as the corresponding immunity components (Hardy, 1975).

As part of a study of ColV-encoded proteins and of the role of ColV plasmids in pathogenicity, $\mathrm{ColV}^{+}$derivatives of the minicell producer P678-54 and its ompA mutant have been made (Moores \& Rowbury, 1982; Rowbury et al., 1985). It has previously been shown (Manning et al., 1977 ) that $\operatorname{omp} A$ mutants grow poorly in minimal medium at $42^{\circ} \mathrm{C}$. During the present work it was noticed that an ompA mutant of strain P678-54 grew poorly in a number of minimal media and failed to form colonies at $44^{\circ} \mathrm{C}$ on glucose minimal media; the same was true for two other omp $A$ mutants tested. This communication reports that the presence of ColV, I-K94 in any of these omp $A$ mutants reverses this $44^{\circ} \mathrm{C}$ growth lesion.

\section{METHODS}

Bacterial strains. All strains used here except the colicin L producer (Serratia marcescens JF 246) were of $E$. coli. Most of these were derived from $E$. coli K12, but two strains used in ColV plasmid transfer (E. coli dig 41 and raw 8) were isolates from sewage (ColV-41 and ColV-8 derive from these). The plasmid ColV-M40(5) is a mutant form of ColV, I-K94 which forms virtually no VmpA protein in P678-54 ompA. The origin and characteristics of strains P678-54, PCO 479 and 1131 ompA were described by Rossouw \& Rowbury (1984). From P678-54,ompA mutants were prepared by plating organisms with excess phage $\mathrm{K} 3$ and isolating resistant colonies. All non-mucoid strains resistant to phage K3 map at the ompA locus (Manning et al., 1976; Henning et al., 1976) but the omp $A$ strains used here were also resistant to phage TuII* and to colicin L and were devoid of OmpA protein. One ompA mutant of strain P678-54 was used to prepare plasmid-bearing strains. After construction (see below), all plasmid-bearing derivatives of $o m p A$ mutants were examined for the presence of the OmpA protein in their membranes, by SDSPAGE of membranes prepared as described below, and were tested for sensitivity to phage K 3 and colicin L. All the plasmid-bearing ompA derivatives were devoid of OmpA protein; except for $\mathrm{R}^{4} 3 \mathrm{ColIa}^{+}$derivatives, they were all resistant to phage K3 and colicin L. All four tested R483 Colla ${ }^{+}$derivatives from P678-54 ompA proved sensitive to phage $\mathrm{K} 3$ and colicin $\mathrm{L}$ although their membranes were devoid of OmpA protein. It is assumed that this resistance plasmid encodes an envelope component which allows attachment/conduction of these inhibitory agents.

Derivatives of strain 1829 carrying ColV, I-K94 and other F-like plasmids were used as donors in conjugation. These strains have been described by Rossouw \& Rowbury (1984) and Rowbury et al. (1985).

Growth media. The minimal medium used for growth was that of Davis \& Mingioli (1950) with glucose $(0.2 \%$, $\mathrm{w} / \mathrm{v})$ as energy source and with required DL-amino acids added at $20 \mu \mathrm{g} \mathrm{ml}^{-1}$ and other growth factors at $5 \mu \mathrm{g} \mathrm{ml}^{-1}$. This medium is referred to in the text as supplemented glucose MM. In some experiments, glucose was replaced with other energy sources and ammonium sulphate with other nitrogen sources. The enriched medium was Oxoid no. 2 broth (broth). Where required, these media were solidified with $2 \%(\mathrm{w} / \mathrm{v})$ Difco Bacto agar to give supplemented glucose MA and NA.

Plasmid transfer by conjugation. Derivatives of strain 1131 and strain P678-54 ompA carrying F-like plasmids were made either by plasmid transfer in nutrient broth at $37^{\circ} \mathrm{C}$ with gentle shaking (Rossouw \& Rowbury, 1984) using derivatives of E. coli 1829 (Rowbury et al., 1985) as donors, or by filter conjugation. For this purpose, unless otherwise stated, donor strains were derivatives of strain $1829 ; 1 \mathrm{ml}$ samples of donor and recipient strains grown to exponential phase (about $2 \times 10^{8}$ organisms $\mathrm{ml}^{-1}$ ) in nutrient broth at $37^{\circ} \mathrm{C}$ were filtered onto $0.22 \mu \mathrm{m}$ pore size Millipore filters (sterilized by UV irradiation) and filters incubated on nutrient agar plates for $2-3 \mathrm{~h}$ at $37^{\circ} \mathrm{C}$. After 
incubation, filters were transferred to $2 \mathrm{ml}$ supplemented glucose $\mathrm{MM}$ and, after dilution, cells were plated on appropriate selective media.

Growth and tests for colony formation on minimal agar. Organisms were grown overnight with shaking at $37^{\circ} \mathrm{C}$ in supplemented glucose MM, then diluted (time zero) 40-fold into the same medium and growth continued with shaking at $37^{\circ} \mathrm{C}$. At time zero and after $24 \mathrm{~h}$, samples of suitable dilutions were plated on supplemented glucose MA and plates incubated at 30,37 and $44^{\circ} \mathrm{C}$. Colonies were counted after $48-72 \mathrm{~h}$.

Membrane preparation, separation and analysis. For analysis of membranes for presence or absence of the OmpA protein, the organisms were grown in broth and membranes prepared and analysed by SDS-PAGE as described by Rossouw \& Rowbury (1984). For separation of membrane fractions, organisms were lysed and membranes prepared as described by Ito et al. (1977) and Burnell et al. (1980). Fractions were analysed as described by Rossouw \& Rowbury (1984). For preparation and use of activated dextran, the procedure of Kamio \& Nikaido (1977) was used, membrane fractions being prepared and analysed as above.

Where appropriate, gels were scanned with a Joyce-Loebl Chromoscan 3.

Antibody preparation. The VmpA protein and OmpA protein were partially purified from strains $\mathrm{P} 678-54 \mathrm{ompA}$ ColV, I-K94+ and P678-54 omp $A^{+}$, respectively, as follows. Outer membrane peptidoglycan complexes were prepared as described by Burnell et al. (1980), washed in $50 \mathrm{mM}-\mathrm{Tris} / \mathrm{HCl} \mathrm{pH} 8.0$ and then incubated in the extraction buffer of Rosenbusch (1974) for $30 \mathrm{~min}$ at $60^{\circ} \mathrm{C}$. The mixture was then diluted with an equal volume of the same buffer and centrifuged at $110000 \mathrm{~g}$ for $45 \mathrm{~min}$ at $20^{\circ} \mathrm{C}$. The proteins in the soluble fraction were precipitated with $95 \%(\mathrm{v} / \mathrm{v})$ ethanol at $-70^{\circ} \mathrm{C}$ and collected by centrifugation $\left(35000 \mathrm{~g}\right.$ for $30 \mathrm{~min}$ at $\left.4{ }^{\circ} \mathrm{C}\right)$. The pellet was suspended in SDS sample buffer (Rossouw \& Rowbury, 1984) heated at about $100^{\circ} \mathrm{C}$ for $5 \mathrm{~min}$ and samples were run on a polyacrylamide gel. After electrophoresis, the required bands were sliced out, crushed and the crushed fragments wetted with a small volume of $0.1 \mathrm{M}$-Tris/ $\mathrm{HCl}$ buffer $\mathrm{pH} 7.0$ containing $0.1 \%(\mathrm{w} / \mathrm{v}$ ) SDS. The proteins were eluted from the wetted gel by 2 vols $0.1 \mathrm{M}-\mathrm{Tris} / \mathrm{HCl} \mathrm{pH} 7.0$ containing $0.1 \%$ (w/v) SDS, concentrated by precipitation with $90 \%(\mathrm{v} / \mathrm{v})$ acetone overnight at $-20{ }^{\circ} \mathrm{C}$ and the protein recovered from several

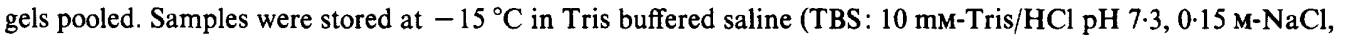
$1 \mathrm{~mm}$-EDTA) or phosphate buffered saline $\left(0.14 \mathrm{M}-\mathrm{NaCl}, 2.7 \mathrm{~mm}-\mathrm{KCl}, 1.5 \mathrm{~mm}-\mathrm{KH}_{2} \mathrm{PO}_{4}, 8.1 \mathrm{~mm}-\mathrm{Na}_{2} \mathrm{HPO}_{4}\right.$ $\mathrm{pH} 7.3$ ) in $0.5 \mathrm{ml}$ samples with protein at about $10 \mathrm{mg} \mathrm{ml}^{-1}$.

The partially purified proteins $(0.5 \mathrm{mg})$ were mixed with Freund's complete adjuvant $(0.2 \mathrm{ml})$ and injected intramuscularly into separate rabbits. Booster injections (about $0.2 \mathrm{mg}$ protein) were given at 2 week intervals for 6 weeks; 3 weeks after the third booster, large blood samples were taken by heart puncture. Serum was collected and stored frozen at $-20^{\circ} \mathrm{C}$ in $0.5 \mathrm{ml}$ samples.

Antibody adsorption. Cell envelopes [prepared by the method of Ito et al. (1977)] from strain P678-54 ompA were washed in TBS by centrifugation and then heated at $100^{\circ} \mathrm{C}$ for $15 \mathrm{~min}$ in TBS containing $0.1 \%(\mathrm{w} / \mathrm{v}) \mathrm{SDS}$ and $5 \%$ ( $\mathrm{v} / \mathrm{v})$ glycerol. After cooling, samples were mixed with equal quantities of each of the sera at $1 \mathrm{mg}$ or $10 \mathrm{mg}$ protein $\mathrm{ml}^{-1}$ and incubated for $2 \mathrm{~h}$ at $37^{\circ} \mathrm{C}$ followed by $17 \mathrm{~h}$ at $4{ }^{\circ} \mathrm{C}$. The envelope-antiserum mixture was centrifuged at $10000 \mathrm{~g}$ for $15 \mathrm{~min}$ at $4{ }^{\circ} \mathrm{C}$ and the supernatant (representing adsorbed antiserum) collected and used as described below.

Ouchterlony tests. All antisera and agars were prepared in or diluted with TBS, whereas dilutions of antigen were made in TBS containing $1 \%(\mathrm{v} / \mathrm{v})$ Triton X-100. Ouchterlony plates $[1 \%(\mathrm{w} / \mathrm{v})$ agar containing $0.02 \%$ sodium azide] were prepared in $25 \mathrm{ml}$ Petri dishes with $3 \mathrm{~mm}$ holes around a central hole. Antigen, i.e. the appropriate partially purified protein or cell envelope preparation [prepared by the method of Ito et al. (1977)] at a protein level of about $10 \mathrm{mg} \mathrm{ml}^{-1}$, was heated at $100{ }^{\circ} \mathrm{C}$ for $15 \mathrm{~min}$ in TBS containing $1 \% \mathrm{SDS}$ and $5 \%$ glycerol and, after dilution, $10 \mu \mathrm{l}$ of each concentration (undiluted and 2-, 4-, 8-, 16- and 32-fold diluted) placed into the outer wells while $10 \mu \mathrm{l}$ of undiluted or two- or fourfold diluted antiserum was placed in the centre well. Control experiments were done in parallel using pre-immune serum. Plates were kept in a humid atmosphere at room temperature for 24-48 $\mathrm{h}$ and then stained with Coomassie Blue to enhance the precipitin lines.

\section{RESULTS AND DISCUSSION}

\section{Growth of ompA mutants at $44^{\circ} \mathrm{C}$}

Organisms of strain P678-54, after growth in supplemented glucose $\mathrm{MM}$ at $37^{\circ} \mathrm{C}$, formed colonies when plated on supplemented glucose MA at 30,37 or $44^{\circ} \mathrm{C}$ (Table 1), although sometimes the number of colonies formed at $44^{\circ} \mathrm{C}$ was somewhat less than at 30 or $37^{\circ} \mathrm{C}$ (Table 1 ). In contrast, organisms of P678-54 ompA formed colonies on supplemented glucose MA at 30 and $37^{\circ} \mathrm{C}$ but not at $44^{\circ} \mathrm{C}$ (Table 1). Organisms of the ompA mutant formed colonies on NA or MA + Casamino acids at $44^{\circ} \mathrm{C}$ but not on supplemented glucose MA or on supplemented glucose MA plus individual amino acids. In the latter studies, each of the 18 common protein amino acids (other than threonine and leucine, which were present in all cases) was tested individually 
Table 1. Effect of ColV,I-K94 on growth at $44^{\circ} \mathrm{C}$

Bacteria were grown in supplemented glucose MM shaken at $37^{\circ} \mathrm{C}$ and plated after $24 \mathrm{~h}$. Colony no. is given as a percentage of that at $30^{\circ} \mathrm{C}$.

\section{E. coli strain}

P678-54 ompA $A^{+}$

P678-54 ompA

P678-54 ompA ColV, I-K94

P678-54 ompA, cured*

P678-54 ompC ompA

P678-54 ompC ompA ColV, I-K94

PCO479 ompA $A^{+}$

1131 ompA†

1131 omp $A$ ColV, I-K94
Relative no. of colonies formed on supplemented glucose MA at:

$\begin{array}{rr}37{ }^{\circ} \mathrm{C} & 44{ }^{\circ} \mathrm{C} \\ 87 & 37 \\ 72 & 0 \\ 187 & 75 \\ 116 & 0 \\ 98 & 0 \\ 85 & 17 \\ 103 & 100 \\ 105 & 0 \\ 104 & 91\end{array}$

* This is a $\mathrm{Col}^{-}$strain derived from P678-54 ompA ColV, I-K 94 by a temperature regime (Rowbury et al., 1985).

$\dagger$ Derived from PCO479.

(in the DL form except for glycine) and some were also tested in pairs (methionine plus cysteine, isoleucine plus valine, glutamate plus glutamine and aspartate plus asparagine); none was able to allow growth of P678-54 ompA on supplemented glucose MA at $44^{\circ} \mathrm{C}$.

Strain 1131, an ompA derivative of PCO 479 (Lugtenberg et al., 1975), also failed to form colonies on supplemented glucose MA at $44^{\circ} \mathrm{C}$, unlike the $o m p A^{+}$parent (Table 1). The same was true for a double ompCompA mutant derived from P678-54.

Even at $37^{\circ} \mathrm{C}$, the growth lesion was apparent in the omp $A$ mutants. Although colonies were formed on supplemented glucose MA at $37^{\circ} \mathrm{C}$, growth was slower, so that whereas colonies of the $o m p A^{+}$parents on this medium were easily visible after $16 \mathrm{~h}$ at $37^{\circ} \mathrm{C}$, the colonies of the $o m p A$ mutants could not be seen with the naked eye at this time.

\section{Effect of ColV, I-K94 on growth at $44^{\circ} \mathrm{C}$}

Although P678-54 omp $A$ grew poorly in liquid minimal medium at $37^{\circ} \mathrm{C}$, on introduction of ColV, I-K94, the derivative behaved like the parental P678-54. The ColV, I-K94 ${ }^{+}$derivative isolated from P678-54 ompA formed colonies normally on supplemented glucose MA at $44^{\circ} \mathrm{C}$ (Table 1). The same was true for ColV, I-K94+ derivatives of strains 1131 and P678-54 ompC $o m p A$. The introduction of ColV, I-K94 also led to better growth of $o m p A$ mutants on supplemented glucose MA at $37^{\circ} \mathrm{C}$. Colonies were, as for the $o m p A^{+}$strains, visible to the naked eye after $16 \mathrm{~h}$ incubation, whereas this was not so for the $\mathrm{Col}^{-}$omp $A$ strains.

It seemed likely that the presence of ColV, I-K 94 in the ompA strains suppressed the growth lesion. Another possibility, however, was that the plasmid had been introduced into mutants carrying normal or altered OmpA protein, these mutants being already present in the omp $A$ cultures. Since $o m p A$ mutants are $\mathrm{Con}^{-}$with respect to F-like plasmids such as ColV, I-K94, any such variants might be more efficient recipients for the plasmid. Several findings rule out this possibility. Firstly, the ColV, I-K94+ derivatives arising from the ompA mutants showed no OmpA protein in their outer membranes (Fig. 1), nor any new protein of similar $M_{\mathrm{r}}$ (i.e. a possible OmpA protein variant), except for the VmpA protein, which is known to be plasmidencoded (Moores \& Rowbury, 1982; Rowbury et al., 1985). Secondly, none of the ColV, I-K94+ derivatives tested showed sensitivity to phage $\mathrm{K} 3$ or colicin $\mathrm{L}$ (sensitivity depends on the presence of OmpA protein). Thirdly, a cured derivative isolated from the omp $A \mathrm{ColV}^{+}$strain by a $42^{\circ} \mathrm{C}$ growth regime (Rowbury et al., 1985) had lost both the plasmid and the ability to grow at $44^{\circ} \mathrm{C}$ on supplemented glucose MA (Table 1).

Other F-like plasmids tested did not suppress the $44^{\circ} \mathrm{C}$ growth lesion; derivatives of strain P678-54 ompA carrying F lac, RI, ColB-K 98 or R124 failed to form colonies on supplemented glucose MA at $44^{\circ} \mathrm{C}$ (Table 2). 
(a)

(b)

(c)

(d)

(e) $\quad(f) \quad(g)$

(h)

$(j)$

(k)

(l) $\quad(m)$

(n)
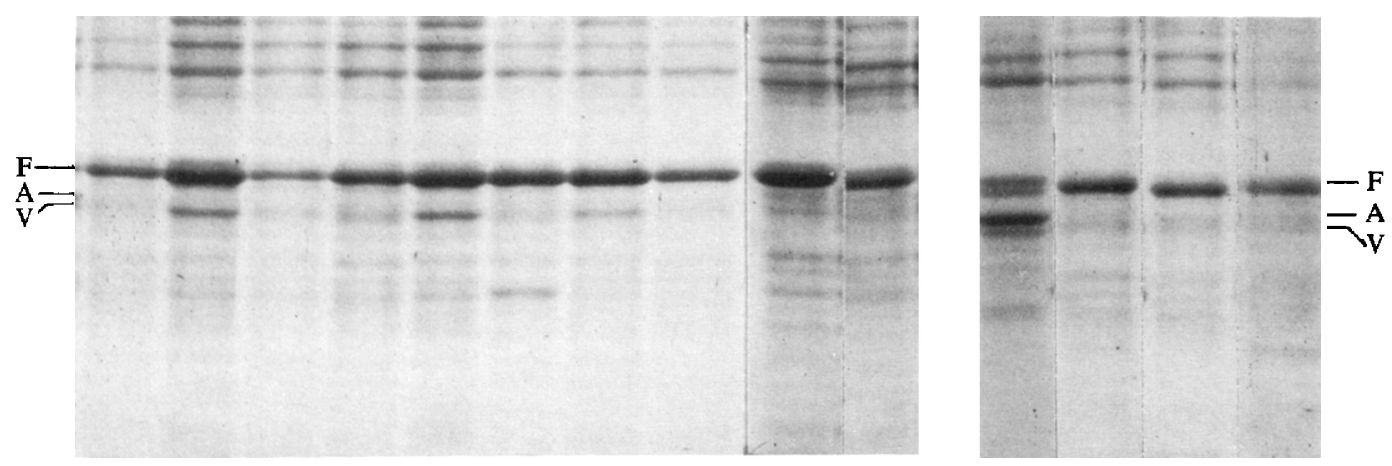

Fig. 1. VmpA protein in ColV, I-K94+ strains of $E$. coli. P678-54 ompA and derivatives were grown in broth at $37^{\circ} \mathrm{C}$ and whole membrane preparations isolated, analysed and run on SDS-PAGE gels. (a) P678-54 ompA; (b) P678-54 ompA ColV, I-K94; (c) P678-54 ompA, cured; (d) P678-54 ompA R124; (e) P678-54 ompA ColV,I-K94, R124; ( $f$ ) P678-54 ompA ColB-K98; (g) P678-54 ompA ColV, I-K94, ColB-K98; ( h) P678-54 ompA ColV-41; (i) P678-54 ompA ColV-M40(5); ( $j$ ) P678-54 ompA ColV-8; $(k)$ P678-54 omp A ${ }^{+}$ColV, I-K94; (l) P678-54 ompA F lac; ( $m$ ) P678-54 ompA R483 Colla; $(n)$ P678-54 ompA RI. Positions of OmpF protein (F), OmpA protein (A) and VmpA protein (V) are arrowed.

Table 2. Plasmids and growth on supplemented glucose $M A$ at $44^{\circ} \mathrm{C}$

Bacteria were grown and plated as described in Table 1.

\begin{tabular}{|c|c|c|c|c|c|c|}
\hline \multirow{2}{*}{$\begin{array}{l}\text { Plasmid(s) } \\
\text { present in } \\
\text { P678-54 } \\
\text { ompA }\end{array}$} & \multicolumn{4}{|c|}{ Plasmid properties } & \multicolumn{2}{|c|}{$\begin{array}{c}\text { Relative colony } \\
\text { no. } \dagger \text { on } \\
\text { supplemented } \\
\text { glucose MA at: }\end{array}$} \\
\hline & $\begin{array}{l}\text { Incompatibility } \\
\text { group }\end{array}$ & $\begin{array}{c}\text { Transfer } \\
\text { properties }\end{array}$ & Colicins & Resistances* & $37^{\circ} \mathrm{C}$ & $44^{\circ} \mathrm{C}$ \\
\hline None & NA & None & None & None & 75 & 0 \\
\hline ColV, I-K94 & FI & Derepressed & $\mathrm{V}, \mathrm{Ia}$ & None & 105 & 61 \\
\hline F lac & FI & Derepressed & None & None & 115 & 0 \\
\hline RI & FII & Repressed & None & $\mathrm{Ap}, \mathrm{Sm}, \mathrm{Cm}, \mathrm{Su}, \mathrm{Km}$ & 107 & $0 \ddagger$ \\
\hline ColB-K98 & FIII & Repressed & $\mathrm{B}, \mathrm{M}$ & None & 163 & 0 \\
\hline $\mathrm{R} 124$ & FIV & Repressed & None & Tc & 48 & 0 \\
\hline R483 ColIa & I & Repressed & Ia & $\mathrm{Sm}, \mathrm{Tp}$ & 92 & 0 \\
\hline $\begin{array}{c}\text { ColV, I-K94, } \\
\text { ColB-K98 }\end{array}$ & FI. FIII & Repressed & V, Ia, B, M & None & 68 & 86 \\
\hline $\begin{array}{l}\text { Colv, I-K 94, } \\
\text { R124 }\end{array}$ & FI, FIV & Repressed & $\mathrm{V}, \mathrm{Ia}$ & $\mathrm{Tc}$ & 82 & 30 \\
\hline
\end{tabular}

NA, Not applicable.

*Ap, ampicillin; Cm, chloramphenicol; Km, kanamycin; Sm, streptomycin; Su, sulphonamides; Tc, tetracycline; Tp, trimethoprim.

+ Colony no. is given as a percentage of that at $30^{\circ} \mathrm{C}$

¥ Slight background growth.

Plasmid components and growth at $44^{\circ} \mathrm{C}$

Presumably, it is a ColV, I-K94-encoded outer membrane protein which suppresses the growth lesion. A number of ColV, I-K 94 transfer components, including the TraT gene product, are located in the outer membrane. It is, however, unlikely that any of them are responsible for the suppression, since the introduction of a $f^{+}$plasmid, such as R124 or ColB-K 98, into P678-54 omp $A$ ColV, I-K94 did not abolish growth on supplemented glucose MA at $44^{\circ} \mathrm{C}$ (Table 2), although the presence of the $f^{+}$plasmids abolished transfer properties, MS2 phage sensitivity and the formation of transfer components such as the TraT product. Additionally, the transfer properties of $\mathrm{F}$ lac are very similar to those of ColV, I-K94 (Hardy, 1975), but F lac did not suppress the $44^{\circ} \mathrm{C}$ growth lesion in the omp $A$ mutant (Table 2). 


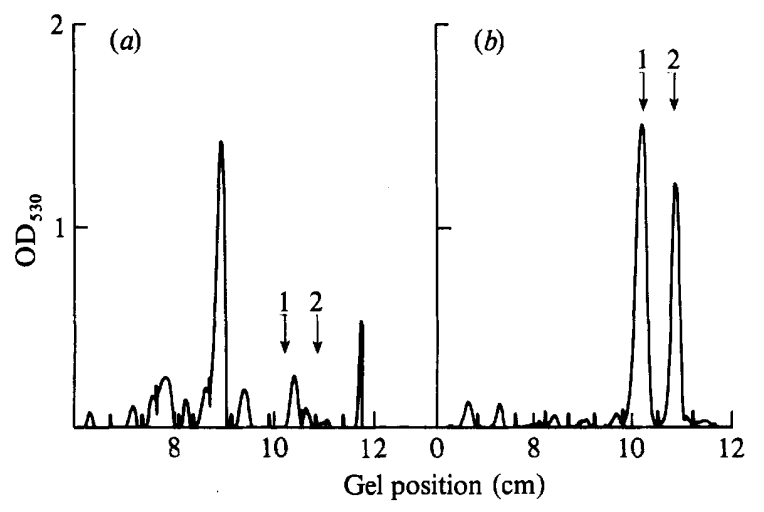

Fig. 2. Location of the VmpA protein. Membranes from P678-54 ompA ColV, I-K94 were prepared and separated by the method of Burnell et al. (1980) and analysed, run by PAGE and scanned as described in Methods. (a) Cytoplasmic membrane fraction; $(b)$ outer membrane fraction. The positions of the porins (1) and VmpA protein (2) are arrowed.

It is unlikely that the presence of colicin $\mathrm{V}$ and its immunity component in the outer membrane is, alone, able to suppress the omp $A$ growth lesion, because introduction of ColV-41 or ColV-8 (ColV plasmids from $E$. coli isolates from sewage), which encode colicin V and its immunity component, failed to allow growth of the $o m p A$ mutant on supplemented glucose MA at $44^{\circ} \mathrm{C}$.

A plasmid which encodes colicin Ia and its immunity component (R483 ColIa) also failed to suppress the $o m p A$ growth lesion (Table 2). Strikingly, this plasmid appears to encode sensitivity to phage $\mathrm{K} 3$ and colicin L. In spite of this sensitivity, all tested R483 ColIa ${ }^{+}$derivatives of P67854 (see Methods) were devoid of the OmpA protein (Fig. 1). It is possible that these strains contain a trace of this protein, not detected on PAGE, or alternatively, this plasmid may confer a new protein present in low amounts or masked, perhaps because of its size, by other outer membrane proteins. For example, a smaller protein, related to the OmpA protein but missing part of the $\mathrm{C}$ terminus, might confer sensitivity to phage $\mathrm{K} 3$ and colicin $\mathrm{L}$, but be masked by other proteins or be present at low level; a larger protein with a similar $\mathrm{N}$-terminus might be masked by the porins.

Some ColV plasmids encode an iron chelation system which uses plasmid-encoded outer membrane proteins for transport. It is very unlikely that a component of such a system is involved in suppression of the ompA growth lesion because ColV, I-K94 apparently does not encode this system (Williams, 1979).

The ColV, I-K 94 plasmid, like most ColV plasmids, encodes the VmpA protein. This is, like the OmpA protein, located exclusively in the outer membrane. This was established by analysing cytoplasmic membrane and outer membrane fractions from P678-54 ompA and P67854 omp $A$ ColV, I-K94. The porins (in both strains) and the VmpA protein (in P678-54 ompA ColV, I-K94) were almost exclusively in the outer membrane fractions (Fig. 2). Moreover, it appears that, like the OmpA protein, the VmpA protein spans the outer membrane, with segments protruding on both sides. The trypsin sensitivity of the VmpA protein in membrane preparations (giving rise to a fragment with an $M_{\mathrm{r}}$ of about 31000 ) but not in whole cells suggests that a segment (probably about 10-20 amino acid residues in length) extends inwards into the periplasmic space (Moores \& Rowbury, 1982; Rowbury et al., 1985). That a part of the VmpA protein protrudes to the outside is suggested by the finding that when cyanogen bromideactivated dextran is added to whole cells of P678-54 ompA ColV, I-K94 and membranes prepared from them, then the level of VmpA protein is reduced about eightfold compared to that in the control membranes from cells not treated with activated dextran (Fig. 3); a similar reduction occurs for the porins (Fig. 3). This indicates that most of the VmpA protein has reacted with the non-penetrating activated dextran and must therefore protrude to the outside. 


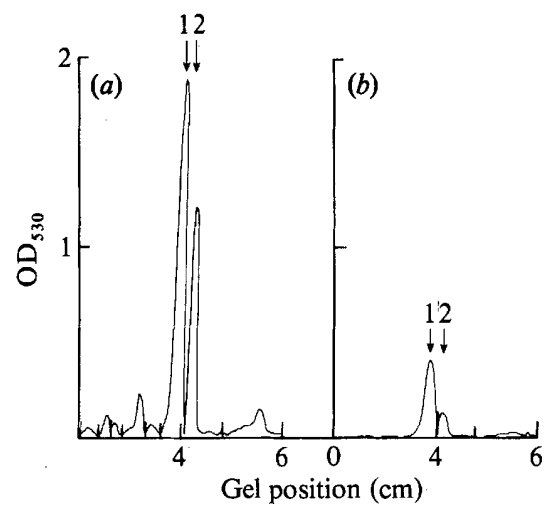

Fig. 3. Reaction of outer membrane proteins with cyanogen bromide-activated dextran. Whole cells of P678-54 ompA ColV, I-K94 were treated with cyanogen bromide-activated dextran. Outer membrane fractions from $(a)$ untreated and $(b)$ treated organisms were then analysed, run by SDS-PAGE and scanned as described in Methods. The positions of the porins (1) and VmpA protein (2) are arrowed. Equal amounts of protein were loaded for each sample but 3.07 times as much protein from the untreated sample entered the gel as for the treated sample.

\section{Table 3. Immunological relatedness of OmpA protein and VmpA protein}

Sera were used undiluted; essentially identical results were obtained with two- or fourfold diluted sera.

\begin{tabular}{|c|c|c|c|c|c|c|c|c|c|}
\hline \multirow[b]{3}{*}{ Sera } & \multirow{3}{*}{$\begin{array}{l}\text { Membranes } \\
\text { used for } \\
\text { adsorption }\end{array}$} & \multicolumn{8}{|c|}{ Extent of reaction with antigen: } \\
\hline & & \multicolumn{3}{|c|}{$\begin{array}{l}\text { VmpA protein } \\
\text { at dilution: }\end{array}$} & \multicolumn{3}{|c|}{$\begin{array}{l}\text { OmpA protein } \\
\text { at dilution: }\end{array}$} & \multirow{2}{*}{$\begin{array}{l}\text { OmpC } \\
\text { protein } \\
\text { undiluted }\end{array}$} & \multirow{2}{*}{$\begin{array}{l}\text { OmpF } \\
\text { protein } \\
\text { undiluted }\end{array}$} \\
\hline & & None & $\times 8$ & $\times 32$ & None & $\times 8$ & $\times 32$ & & \\
\hline Pre-immune serum & None & - & - & - & - & - & - & - & - \\
\hline $\begin{array}{l}\text { Adsorbed serum raised } \\
\text { against VmpA } \\
\text { protein }\end{array}$ & $\mathrm{P} 678-54$ ompA & ++ & ++ & + & ++ & ++ & + & - & - \\
\hline $\begin{array}{l}\text { Adsorbed serum raised } \\
\text { against OmpA } \\
\text { protein }\end{array}$ & P678-54 ompA & ++ & ++ & + & +++ & ++ & + & - & - \\
\hline
\end{tabular}

Additionally, the VmpA protein resembles the OmpA protein in certain properties such as solubility in $2 \%$ SDS at $60{ }^{\circ} \mathrm{C}$ (Moores \& Rowbury, 1982) and its derivation from a slightly larger pro-protein precursor (Rowbury et al., 1985).

The OmpA and VmpA proteins appear to be immunologically related. To demonstrate this, partially purified OmpA and VmpA proteins (see Methods) were tested for reaction with antibodies raised against the corresponding purified proteins. The methods used to prepare the antigens (see Methods) ensured that the partially purified VmpA protein contained no OmpA protein and similarly that the partially purified OmpA protein contained no VmpA protein (accordingly, the serum raised against each protein was free from specific antibodies against the other). Pre-immune sera gave no reaction when tested against any of the dilutions (1/1 to $1 / 32)$ of partially purified porins, OmpA protein or VmpA protein. Partially purified porins gave no reaction at any of the tested dilutions (1/1 to $1 / 32)$ with adsorbed sera raised against $\mathrm{VmpA}$ protein or OmpA protein. In contrast, all tested dilutions of VmpA protein gave marked precipitin reactions with adsorbed serum raised against OmpA protein and vice versa; the patterns of interaction were essentially identical for each antibody with its own antigen and with the other antigen (Table 3). 
These similarities between the two proteins suggested that the VmpA protein might be a plausible replacement for certain OmpA protein functions. Three findings are in accord with the VmpA protein being responsible for suppressing the $44^{\circ} \mathrm{C}$ growth lesion in omp $A$ mutants. Firstly, three ColV plasmids, which either do not encode the VmpA protein (ColV-41 and ColV8), or fail to confer VmpA protein synthesis on strain P678-54 ompA [ColV-M40(5)], did not allow growth of P678-54 ompA on supplemented glucose MA at $44^{\circ} \mathrm{C}$; in contrast, ColV-K 30 , which like ColV, I-K94 encodes the VmpA protein (Williams, 1979), allowed growth of P678-54 $o m p A$ on supplemented glucose MA at $44^{\circ} \mathrm{C}$. The failure of the other tested plasmids to suppress the growth lesion (Table 2) accords with none of them leading to the synthesis of appreciable amounts of VmpA protein (Fig. 1). Secondly, prior growth with magnesium or calcium ions (0.005-0.05 M) prevented colony formation by P678-54 ompA ColV, I-K94 on supplemented glucose MA at $44{ }^{\circ} \mathrm{C}$. Cells grown under these conditions failed to form VmpA protein. Thirdly, organisms of P678-54 ompA ColV, I-K94 also failed to form colonies on supplemented MA at $44^{\circ} \mathrm{C}$ if grown static rather than shaken at $37^{\circ} \mathrm{C}$ prior to plating. Organisms of this (and other $\mathrm{ColV}^{+}$strains) failed to form the VmpA protein in static culture.

\section{Survival of ompA strains on supplemented glucose $M A$ at $44^{\circ} \mathrm{C}$}

Low power microscopy of supplemented glucose MA plates which had been seeded with P678-54 omp A and then incubated at $44^{\circ} \mathrm{C}$ for $40 \mathrm{~h}$ showed the presence of microcolonies; i.e. some growth and division took place at this temperature. It seemed possible, therefore, that the elevated temperature had led to starvation for some component rather than having a more profound effect, e.g. on membrane integrity. Accordingly, survival of the omp $A$ mutants on supplemented glucose MA at $44^{\circ} \mathrm{C}$ was examined by shifting plates to $30^{\circ} \mathrm{C}$ after $16 \mathrm{~h}$ at $44^{\circ} \mathrm{C}$. Most of the organisms formed colonies under these conditions; i.e. they had not been killed by incubation at $44^{\circ} \mathrm{C}$.

One possible cause of starvation might be the failure of $o m p A$ organisms to synthesize a specific metabolite at $44^{\circ} \mathrm{C}$. A mixture of amino acids allowed growth on supplemented glucose MA at $44^{\circ} \mathrm{C}$ and, accordingly, the synthesis of one or more of these might be aberrant. No individual amino acid allowed growth at $44{ }^{\circ} \mathrm{C}$; even $\mathrm{L}$-methionine (the synthesis of which is switched off at elevated temperature; Ron, 1975) on its own or together with L-cysteine was ineffective.

Alternatively, starvation might result from a failure of essential components of the growth medium to permeate at a sufficient rate at $44^{\circ} \mathrm{C}$ into omp $A$ organisms; such organisms are claimed to have permeability defects (Manning et al., 1977). Growing on minimal medium, the organism has to make all its sulphur compounds from sulphate, all its nitrogen-containing ones from $\mathrm{NH}_{4}^{+}$, and has to provide energy and carbon skeletons from glucose. However, an uptake defect for sulphate is unlikely to be the sole cause of growth failure at $44{ }^{\circ} \mathrm{C}$, because supplementation of minimal medium with L-methionine plus L-cysteine did not allow growth at $44^{\circ} \mathrm{C}$, but adding the other 18 (non-sulphur-containing) amino acids allowed growth. If uptake of ammonium ions were aberrant, this would lead to a reduction in synthesis of most or all nitrogenous cellular components. Such a defect would be in accord with the observations because a mixture of amino acids would have a 'sparing' effect and, therefore, might allow growth. If there were a specific defect in uptake of ammonium ions then P678-54 ompA should grow on supplemented glucose MA at $44^{\circ} \mathrm{C}$ if other nitrogen sources were provided. This is not so. Replacement of ammonium sulphate with glutamic acid did not allow growth of P678-54 omp $A$ on supplemented MA at $44^{\circ} \mathrm{C}$ although glutamic acid $\left(250 \mu \mathrm{g} \mathrm{ml}^{-1}\right.$; L-form) is an effective nitrogen source for P678-54 ompA on supplemented glucose MA at 30 or $37^{\circ} \mathrm{C}$ and for P678-54 omp $A^{+}$and P678-54 ompA ColV, I-K94 at 30,37 or $44^{\circ} \mathrm{C}$ on the same medium. Accordingly, if the growth lesion involves a defect in uptake of ammonium ions then this defect applies to glutamate as well.

An alternative possibility is that there is a specific glucose uptake defect at $44^{\circ} \mathrm{C}$. This might also be in accord with reversal of the defect by a mixture of amino acids because this could have a sparing effect. If such a specific defect were responsible for failure of the P678-54 omp A strain to grow on supplemented glucose MA at $44^{\circ} \mathrm{C}$, then growth ought to occur if glucose were 
replaced with other energy sources. In fact, no growth of strain P678-54 ompA occurred if glucose was replaced by maltose, glycerol, succinate or acetate $(0 \cdot 2 \%)$, although all of these are effective as energy sources for growth of this strain on supplemented MA at 30 or $37^{\circ} \mathrm{C}$ and for growth of P678-54 omp $A^{+}$and P678-54 ompA ColV, I-K94 at 30, 37 or $44^{\circ} \mathrm{C}$. Accordingly, if failure of the omp $A$ mutant to grow at $44^{\circ} \mathrm{C}$ results from failure of energy sources to permeate, then the failure is general and not specific to glucose.

The authors are grateful to the Science and Engineering Research Council for a project grant to R. J.R. and for a studentship for C.M.M.D. and to the Central Research Fund of the University of London for a grant to R.J.R.

\section{REFERENCES}

Braun, V. (1978). Structure-function relationships of the Gram-negative bacterial cell envelope. Symposia of the Society for General Microbiology 28, 111-138.

Burnell, E., Van Alphen, L., Verkleis, A., De K RuiJfF, B. \& Lugtenberg, B. (1980). ${ }^{31}$ P Nuclear magnetic resonance and freeze fracture electron microscopy studies on Escherichia coli. Biochimica et biophysica acta 597, 518-532.

Chen, R., Schmidmayr, W., Kramer, C. \& Henning, U. (1980). Primary structure of major outer membrane protein II* (OmpA protein) of Escherichia coli. Proceedings of the National Academy of Sciences of the United States of America 77, 4592-4596.

Cole, S. T., Chen-Schmeisser, U., HindennaCh, I. \& Henning, U. (1983). Apparent bacteriophage-binding region of an Escherichia coli $\mathrm{K} 12$ outer membrane protein. Journal of Bacteriology 153, 581-587.

Davis, B. D. \& Mingioli, E. S. (1950). Mutants of Escherichia coli requiring methionine or vitamin B12. Journal of Bacteriology 60, 17-28.

HaRDY, K. G. (1975). Colicinogeny and related phenomena. Bacteriological Reviews 39, 464-515.

Henning, U., HindennaCh, I. \& Haller, I. (1976). The major proteins of the Escherichia coli cell envelope membrane: evidence for the structural gene of protein II*. FEBS Letters 61, 46-48.

Ito, K., Sato, T. \& Yura, T. (1977). Synthesis and assembly of the membrane proteins in $E$. coli. Cell 11, 551-559.

Kamio, Y. \& NiKaIDo, H. (1977). Outer membrane of Salmonella typhimurium. Identification of proteins exposed on cell surface. Biochimica et biophysica acta 464, 589-601.

Lugtenberg, B., Meijers, J., Peters, R., Van Der Hock, P. \& VAN AlPhen, L. (1975). Electrophoretic resolution of the 'major outer membrane protein' of Escherichia coli $\mathrm{K} 12$ into four bands. FEBS Letters 58, 254-258.

LUKTENHAUS, J. F. (1977). Role of major outer membrane protein in Escherichia coli. Journal of Bacteriology 131, 631-637.

Manning, P. A., Puspurs, A. \& Reeves, P. (1976). Outer membrane of Escherichia coli K12: isolation of mutants with altered protein $3 \mathrm{~A}$ by using host range mutants of bacteriophage K3. Journal of Bacteriology 127, 1080-1084.

Manning, P. A., Pugsley, A. P. \& Reeves, P. (1977). Defective growth functions in mutants of Escherichia coli $\mathrm{K} 12$ lacking a major outer membrane protein. Journal of Molecular Biology 116, 285-300.

MoORES, J. C. \& RowburY, R. J. (1982). A new major outer membrane protein in derivatives of Escherichia coli carrying the virulence plasmid ColV-K94. Zeitschrift für allgemeine Mikrobiologie 22, 465-475.

Morona, R., Klose, M. \& Henning, U. (1984). Escherichia coli $\mathrm{K} 12$ outer membrane protein (OmpA) as a bacteriophage receptor: analysis of mutant genes expressing altered proteins. Journal of Bacteriology 159, 570-578.

NiKaIDO, H. (1979). Non-specific transport through the outer membrane. In Bacterial Outer Membranes, pp. 361-408. Edited by M. Inouye. New York: Wiley.

RoN, E. Z. (1975). Growth of enterobacteriaceae at elevated temperatures: limitation by methionine. Journal of Bacteriology 124, 243-246.

RosenbusCh, J. P. (1974). Characterisation of the major envelope protein from Escherichia coli. Regular arrangement on the peptidoglycan and unusual dodecyl sulfate binding. Journal of Biological Chemistry 249, 8019-8029.

Rossouw, F. T. \& RowBURY, R. J. (1984). Effects of the resistance plasmid $\mathrm{R} 124$ on the level of the OmpF outer membrane protein and on the response of Escherichia coli to environmental agents. Journal of Applied Bacteriology 56, 63-79.

Rowbury, R. J., DeEney, C. M., Reakes, C., Rossouw, F. T., Smith, D. G. \& Tewari, R. (1985). Envelope protein changes, autoagglutination, sensitivity to hydrophobic agents and a conditional division lesion in Escherichia coli strains carrying ColV virulence plasmids. Annales de l'Institut Pasteur 136A, 147-157.

Skurray, R. A., Hancock, R. E. W. \& Reeves, P. (1974). Con $^{-}$mutants : class of mutants in Escherichia coli K12 lacking a major cell wall protein and defective in conjugation and adsorption of bacteriophage. Journal of Bacteriology 119, 726-735.

Sonntag, I., Schwarz, H., Hirota, Y. \& Henning, U. (1978). Cell envelope and shape of Escherichia coli: multiple mutants missing the outer membrane lipoprotein and other major outer membrane proteins. Journal of Bacteriology 136, 280-285.

Williams, P. H. (1979). Important component in the virulence of invasive strains of Escherichia coli. Infection and Immunity 26, 925-932. 